\title{
Transport and economic problems of subsoil use in the Russian Far East
}

\author{
Yuliya Arkhipova ${ }^{1, *}$ and Anna Bardal ${ }^{2, \dagger}$ \\ ${ }^{1}$ Mining Institute FEB RAS, 51 Turgenev st., Khabarovsk, 680000, Russia \\ ${ }^{2}$ Federal State Budgetary Institution of Science Economic Research Institute of the Far Eastern \\ Branch of the Russian Academy of Sciences, 680042, Khabarovsk, 153 Tikhookeanskaya Str., Russia
}

\begin{abstract}
The Russian Far East possesses significant reserves of minerals. Mineral resources are rich in species diversity. The development of resources is faced with several problems, such as the depletion of active proven reserves in the exploited fields; high costs of transporting raw materials and finished products to processing sites or end-user markets; lack of availability of deposits; significant financial investments in the construction of new transport routes, etc. This means a transition from the extraction of raw materials to obtaining a product with a high stage of processing and the construction of transport routes. In this article, the authors examined the structure of investments in fixed assets by type of economic activity in the subjects of the Far Eastern Federal District. The values of the volumes of reserves and production of major minerals (for 2018) are presented, and resources are allocated based on which it is necessary to develop processing industries in the region. A comparison is made of the transport accessibility of options for locating a metallurgical plant in the Far East. The conclusion about the need for state support of resource projects and the development of measures to improve the conditions for investment has been substantiated.
\end{abstract}

\section{Introduction}

The territory of the Far East has the richest mineral resources. However, the level of development of production, transport, and energy infrastructure is low. Therefore, the Far East lags significantly behind other regions of Russia in terms of socio-economic development. This leads to an increase in population outflow and other problems. The presence of large reserves of oil, coal, non-ferrous and rare earth metals, as well as the geographical proximity to the actively developing countries of the Asia-Pacific region (APR), including China, suggest that the further development of the Far East will be associated with the strengthening and intensification of economic relations with Asian countries. However, it cannot be ruled out that the natural resources of the Far East may become the main resource and financial base for the development of industries in the event of the economy reorientation to the industrial path of development. The use of the mineral

\footnotetext{
* Corresponding author: arhipova@igd.khv.ru

† Corresponding author: Bardal@ecrin.ru
} 
resource base of the Far East for the creation of industries with a higher added value is today an important condition for the development of Russia.

\section{Problem Statement and Methods}

The level of economic development, on the one hand, is determined, and on the other, it sets the scale of investment activity and activity of enterprises in the region. Some administrative entities of the Far East have a low level of economic development. The economic situation is affected by the remoteness of the Far East from the centers of economic activity in Russia. The development of transport is important due to the large area of the region and the uneven distribution of economic activity in the territory. However, at present, the development of transport infrastructure in the Far East is not enough. This causes limitations on the competitiveness of sectors of the economy. For the development of resource industries, rail and road networks are primarily important.

At the present time, the level of investment in the economy of the Far East is low. As a result, even the process of simple reproduction does not take place. There is no increase in fixed capital, which is necessary for the growth of production and economic development $[1,2]$. Therefore, it is important to create good conditions for investment in the Far East. For this, the state currently uses special economic instruments: territories of advanced socio-economic development, the free port of Vladivostok, regional investment projects, etc. These instruments allow the creation of favourable preferential conditions for investors and increase the investment volume in the Far East.

Despite the measures taken, the volume of investments in fixed assets of the Far Eastern Federal District (FEFD) remains one of the lowest in the country [3]. Consider the structure of investments in the Far East based on official statistics [4]. The main investment trends are:

(1) the share of investments in the FEFD is 9.6\% of the total for Russia;

(2) the largest volumes of investments in the mining industry (456.6 billion rubles), in second place - transport (360.6 billion rubles), in the third - manufacturing industry (133.8 billion rubles);

(3) the leaders among the subjects of the FEFD in terms of investments in the mining industry are: Magadansky region (72.1\%), Sakhalinsky region (70.5\%) and Republic of Sakha (Yakutiya) (48.9\%);

(4) the leaders among the subjects of the FEFD in terms of investments in the transport are: Evrejskaya autonomous district (70.4\%), Amurskaya district (47.7\%) and Khabarovsky Krai (38.4\%);

(5) the leaders among the subjects of the FEFD in terms of investments in the manufacturing industry are the Amurskaya district (34.6\%), Primorskiy Krai (19.1\%), and Khabarovskiy Krai (11.2\%).

This confirm the thesis on the preservation of the transit and export-raw material specialization of the economy of the Far East. The region retains a resource-raw material orientation with insufficient development of processing industries or their absence (Chukotskiy autonomous district). However, the development of methods for the exploitation of deposits and the improvement of the transport system of the region is required for the effective implementation of the resource-transit function of the regional economy [5].

The Far East possesses significant reserves and mineral resources (Table 1). It is necessary to create processing industries in the region, to form new centers for the processing of mineral resources, including in the territories of advanced social and economic development. 
When creating processing enterprises, the Far East could provide them with raw materials for several minerals, meet the demand for finished products, and also export both raw materials and finished products with a high share of VAT.

Table 1. Reserves and production of the main minerals of the Far Eastern Federal District in 2018 [6]

\begin{tabular}{|l|c|c|c|c|c|c|}
\hline \multicolumn{1}{|c|}{ Minerals } & $\begin{array}{c}\text { Reserves } \\
\text { in the } \\
\text { FEFD }\end{array}$ & $\begin{array}{c}\text { Reserves } \\
\text { in Russia }\end{array}$ & $\begin{array}{c}\text { Share of the } \\
\text { FEFD in the } \\
\text { RF by } \\
\text { reserves, } \%\end{array}$ & $\begin{array}{c}\text { Extraction } \\
\text { of minerals } \\
\text { in the } \\
\text { FEFD }\end{array}$ & $\begin{array}{c}\text { Extraction } \\
\text { of minerals } \\
\text { in RF }\end{array}$ & $\begin{array}{c}\text { Share of the } \\
\text { FEFD in the } \\
\text { RF by } \\
\text { production, \% }\end{array}$ \\
\hline Oil, billion tons & 1.1 & 29.8 & 3.7 & 0.029 & 0.52 & 5.6 \\
\hline $\begin{array}{l}\text { Gas, trillion } \\
\text { cubic meters }\end{array}$ & 4.65 & 73 & 6.4 & 0.0103 & 0.047 & 21.9 \\
\hline Coal, billion tons & 35.9 & 275 & 13.1 & 0.07 & 0.398 & 17.5 \\
\hline $\begin{array}{l}\text { Iron ore, billion } \\
\text { tons }\end{array}$ & 11.4 & 112.9 & 10.1 & 0.012 & 0.107 & 11.2 \\
\hline $\begin{array}{l}\text { Manganese ores, } \\
\text { million tons }\end{array}$ & 19.5 & 283.7 & 14.5 & 0 & 0.057 & 0 \\
\hline $\begin{array}{l}\text { Copper, million } \\
\text { tons }\end{array}$ & 36.734 & 99.1 & 37.1 & 0.038 & 0.785 & 4.8 \\
\hline $\begin{array}{l}\text { Lead, million } \\
\text { tons }\end{array}$ & 9.42 & 17.67 & 53.3 & 0.0571 & 0.22 & 26 \\
\hline $\begin{array}{l}\text { Tin, thousand } \\
\text { tons }\end{array}$ & 2110.2 & 2152.5 & 98.0 & 1.2 & 1.9 & 63.2 \\
\hline $\begin{array}{l}\text { Tungsten, } \\
\text { thousand tons }\end{array}$ & 845.1 & 1327.7 & 63.7 & 4.224 & 4.224 & 100 \\
\hline $\begin{array}{l}\text { Molybdenum, } \\
\text { million tons }\end{array}$ & 1.46 & 2.21 & 66.1 & 0 & 0.003 & 0 \\
\hline $\begin{array}{l}\text { Titanium, } \\
\text { million tons }\end{array}$ & 132.8 & 600.40 & 22.1 & 0 & 0.004 & 0 \\
\hline $\begin{array}{l}\text { Zirconium, } \\
\text { million tons }\end{array}$ & 3.09 & 12.33 & 25.1 & 0 & 0.007 & 0 \\
\hline $\begin{array}{l}\text { Rare earth } \\
\text { metals, million } \\
\text { tons }\end{array}$ & 9.3 & 33.1 & 28.1 & 0 & 0.003 & 0 \\
\hline $\begin{array}{l}\text { Silver, thousand } \\
\text { tons }\end{array}$ & 80.12 & 131.25 & 61.0 & 1.379 & 1.4 & 98.5 \\
\hline $\begin{array}{l}\text { Diamonds, } \\
\text { million carats }\end{array}$ & 902.2 & 1136 & 79.4 & 33.2 & 43.2 & 76.9 \\
\hline
\end{tabular}

The most demanded minerals today are oil, gas, non-ferrous and noble metals, diamonds due to the positive world market conditions for them [7]. The second is iron and manganese ores, titanium raw materials, tin, and these are the types on the basis of which it is necessary to develop production in the region, since they have a significant impact on economic development.

Iron ores. The creation of ferrous metallurgy in the Far East region is one of the main tasks at the present time. The construction of a metallurgical complex with a capacity of 5-6 million tons per year based on iron ore raw materials of the Evrejskaya autonomous district and Amurskaya district will lead to the development of the economy based on the integrated development of mineral resources and the final products of metallurgy, will create the preconditions for an accelerated transition to an industrial type of development of the southern part of the FEFD.

Three options for the location of a new metallurgical plant in the Far East are being considered: South Yakutiya (area of Chulman settlement), Amurskaya district (Svobodny city or Fevralsk station), Khabarovsky Krai (Komsomolsk-on-Amur, Tyrma settlement). 
These options provide for various transport schemes for the transportation of raw materials and products. The presented options for the location of metallurgical production differ in transport accessibility (Table 2).

Table 2. Comparison of transport accessibility of options for locating a metallurgical plant in the Russian Far East

\begin{tabular}{|c|c|c|c|}
\hline Location & Railroad availability & Road availability & $\begin{array}{l}\text { Connection to backbone } \\
\text { transport networks }\end{array}$ \\
\hline $\begin{array}{l}\text { South Yakutiya } \\
\text { (area of Chulman } \\
\text { settlement) }\end{array}$ & $\begin{array}{l}\text { Amuro-Yakutsk } \\
\text { Railway }\end{array}$ & $\begin{array}{l}\text { Federal highway A- } \\
360 \text { "Lena" }\end{array}$ & $\begin{array}{l}\text { Baikal-Amur Railway - } \\
\text { Trans-Siberian Railway } \\
\text { and federal highway P- } \\
297 \text { "Amur" }\end{array}$ \\
\hline $\begin{array}{l}\text { Amurskaya district } \\
\text { (1) location near } \\
\text { Svobodny city or } \\
\text { (2) location near } \\
\text { Fevralsk railway } \\
\text { station }\end{array}$ & $\begin{array}{l}\text { (1) location near } \\
\text { Svobodny city: the } \\
\text { section from the Trans- } \\
\text { Siberian Railway to } \\
\text { the border with the } \\
\text { PRC } \\
\text { 2) location near } \\
\text { Fevralsk railway } \\
\text { station: Baikal-Amur } \\
\text { Railway }\end{array}$ & $\begin{array}{l}\text { (1) location near } \\
\text { Svobodny city: there } \\
\text { is a road } \\
\text { 2) location near } \\
\text { Fevralsk: no road }\end{array}$ & $\begin{array}{l}\text { (1) location near } \\
\text { Svobodny city: Trans- } \\
\text { Siberian Railway and } \\
\text { federal highway P-297 } \\
\text { "Amur" } \\
\text { (2) location near } \\
\text { Fevralsk railway station: } \\
\text { Baikal-Amur Railway }\end{array}$ \\
\hline $\begin{array}{l}\text { Khabarovskiy krai } \\
\text { (1) Komsomolsk- } \\
\text { on-Amur city or } \\
\text { (2) location near } \\
\text { Tyrma settlement }\end{array}$ & $\begin{array}{l}\text { (1) Komsomolsk-on- } \\
\text { Amur city: Baikal- } \\
\text { Amur railway } \\
\text { (2) location near } \\
\text { Tyrma settlement: no } \\
\text { railway }\end{array}$ & $\begin{array}{l}\text { (1) Komsomolsk-on- } \\
\text { Amur city: federal } \\
\text { road A-376 } \\
\text { "Khabarovsk-Lidoga- } \\
\text { Vanino with section to } \\
\text { the city of } \\
\text { Komsomolsk-on- } \\
\text { Amur" } \\
\text { (2) location near } \\
\text { Tyrma settlement: no } \\
\text { road }\end{array}$ & $\begin{array}{l}\text { (1) Komsomolsk-on- } \\
\text { Amur city: Baikal-Amur } \\
\text { railway and federal } \\
\text { highway P-297 "Amur" } \\
\text { (2) location near Tyrma } \\
\text { settlement: no railways } \\
\text { and highways }\end{array}$ \\
\hline
\end{tabular}

Source: compiled according to the data of the branch of Russian Railways - Far Eastern Railways, the Federal Road Agency "Rosavtodor".

Thus, when comparing various options for the location of a new metallurgical plant in terms of transport accessibility, the best positions are near the Chulman settlement in the Republic of Sakha (Yakutiya), the Svobodny city in the Amurskaya district and Komsomolsk-on-Amur city in the Khabarovsky Krai.

Manganese ores. The main consumer of manganese ores is ferrous metallurgy. Ores are used as one of the most important components in the production of alloy steel and cast iron as an additive to alloys. The total reserves of manganese ores in the Far East are 19.5 million tons, the predicted resources are more than 200 million tons. Manganese deposits and ore occurrences are found in the Evrejskaya autonomous district, Primorsky Krai, Khabarovsky Krai, Republic of Sakha (Yakutiya), Magadansky district. Currently, their development in the Far East is not carried out due to the complexity for mining, low content of components in a number of deposits. An assessment of new areas is needed to replenish reserves.

In the case of large volumes of ore transportation, the use of railway transport will be most effective. Since there is no information on specific points of production localization, it is difficult to assess the transport accessibility of production facilities. You can use the density of transport networks of the Far Eastern constituent entities of the Russian Federation for a general assessment of transport accessibility (Table 3). 
Table 3. Density of transport networks of the Far East in administrative entities where manganese deposits are located (2018) [8]

\begin{tabular}{|c|c|c|c|}
\hline \multirow{2}{*}{ Subjects of the Russian Federation } & \multicolumn{2}{|c|}{$\begin{array}{l}\text { Density of highways (km per } \\
1000 \text { sq. km) }\end{array}$} & \multirow{2}{*}{$\begin{array}{l}\text { Density of railways } \\
\text { (km per } 1000 \text { sq. km) }\end{array}$} \\
\hline & common use & uncommon & \\
\hline Republic of Sakha (Yakutiya) & 11.5 & 1.8 & 0.2 \\
\hline Kamchatsky Krai & 5.0 & 0.3 & - \\
\hline Primorsky Krai & 112.9 & 11.4 & 9.5 \\
\hline Khabarovsky Krai & 17.8 & 4.4 & 2.7 \\
\hline Magadansky district & 6.5 & 0.6 & - \\
\hline Evrejskaya autonomous district & 79.9 & 1.2 & 14.1 \\
\hline
\end{tabular}

Note: "-" there is no railway.

Titanium raw materials. Deposits and manifestations of titanium-containing ores in the Far East are in the Amurskaya district and the Khabarovsky Krai. There are promising territories for the search for new deposits. Researches (VIMS, DVIMS, LLC "Pigment") have been carried out repeatedly on the possibility of obtaining ilmenite concentrates from the ores of deposits, creating an enterprise for the production of pigment titanium dioxide (based on the Kuranakh deposit). However, the projects have not been implemented, what is associated with the unfinished technologies for the extraction and separation of useful components, or their absence in the Russian Federation. The purchase of foreign technologies and equipment is too expensive for investors.

Tin. The sectoral strategies for the development of the mineral resource complex talk about of the need to develop tin ore processing. More than $90 \%$ of Russia's reserves and resources are concentrated in the Far East, the deposits and occurrences of which are sufficient to create a full-fledged tin mill. However, at present, many previously operating enterprises in almost every subject of the FEFD do not function. Tin is mined only in the Khabarovsky Krai and in the Primorsky Krai. There are many reasons for the closure of enterprises: a decrease in domestic consumption in Russia; depletion of large deposits; low content of tin in the ore, which leads to higher production costs, etc. Despite this, there is a resumption of tin mining in the Far East with government support in the form of tax incentives, etc. The implementation of many large mining projects in the Far East is expected [9]. But there are certain common problems [7].

\section{Results and Discussion}

In the Far East, since 2013, a project has been implemented to develop the Baikal-Amur and Trans-Siberian railways. During the first stage (2013-2019), a number of measures were taken to increase the carrying capacity of the railway. The capacity of the railway in the direction of seaports and border crossings should be increased to 124.4 million tons of coal and ores from deposits [10]. In the Far East, more than 24 stations and siding were reconstructed, two new stations and 17 sidings were built, 1.5 thousand $\mathrm{km}$ of track were laid.

In 2018-2019 work was carried out on the reconstruction of the railway on about. Sakhalin, reconstruction of the Karymskaya-Zabaikalsk section. In the Republic of Sakha (Yakutiya), in 2019, the Tommot-Yakutsk (Nizhny Bestyakh) launch complex was commissioned for permanent operation, regular freight and passenger traffic was opened, and tariffs were equalized to the all-Russian level.

However, despite the ongoing work, the total length of the "bottlenecks" of the FEFD railway network is estimated at more than 3 thousand $\mathrm{km}$ [11]. The pace of development of 
railways lags behind the needs of shippers. The transport factor is a significant limitation of the development of production.

Every year there is a shortage of railway and seaport infrastructure to meet the growing needs of mining companies focused on exporting products. In 2018, the loading of export cargo by rail in the direction of the seaports of the Far East amounted to 98.9 million tons (one-third of the total volume of export cargo). The main cargo is coal; the Far Eastern ports account for half of its transshipment. At the end of 2018, the transshipment of coal in the seaports of the Far East amounted to about 122 million tons (61\% of the total). The coal companies plan to double supplies eastward by 2025 to 207 million tons, including up to 195 million tons by rail. The increase in the production of coal and other resources requires a parallel connection between railway and port facilities. The current carrying capacity of the Baikal-Amur Railway and the Trans-Siberian Railway in the eastern direction is 120 million tons of cargo. The throughput capacity of seaports is 219.2 million tons, including 108.4 million tons for dry cargo. Some seaports of the Far East are already working at the limit or with overload (Table 4).

The demand for coal in Asian countries, against the backdrop of economic sanctions imposed by Western countries, has led to a change in the plans of mining companies and their reorientation to the eastern export direction. This caused a shortage of transshipment capacities for the sea transport of the Far East, the scale of which will increase in the future. There was a shortage of maritime transport capacity. Therefore, coal transshipment in seaports is currently carried out not only by specialized terminals but also by universal ones.

Table 4. Loading of the leading ports of the Far East (2018) [12]

\begin{tabular}{|l|c|c|c|}
\hline \multicolumn{1}{|c|}{ Sea ports } & $\begin{array}{c}\text { Transshipment, } \\
\text { million tons }\end{array}$ & $\begin{array}{c}\text { Throughput, } \\
\text { million tons/year }\end{array}$ & Capacity utilization,\% \\
\hline Vostochniy port & 69.7 & 64.3 & 108.4 \\
\hline Vanino & 29.5 & 25.1 & 117.5 \\
\hline Nakhodka & 24.3 & 26.6 & 91.4 \\
\hline Prigorodnoe & 17.0 & 19.6 & 86.7 \\
\hline Vladivostok & 21.2 & 22.7 & 93.4 \\
\hline
\end{tabular}

In the Far East, specialized coal terminals operate in the ports of Vostochniy (JSC Vostochniy Port), Vanino (JSC Daltransugol), and Posiet (JSC Commercial Port Posiet). These terminals use specialized technological (car dumpers; defrosting installations; systems for cleaning coal from impurities; coal transportation systems, etc.) and environmental protection equipment (irrigation, dust suppression installations, etc.). Coal transshipment in other ports is carried out mainly using grabs that are not equipped with dust suppression systems and coal cleaning from impurities. With the expected excess of demand over supply for port infrastructure services, projects for the construction of new sea terminals are currently being implemented and planned for implementation.

\section{Conclusions}

Without diminishing the importance of the development of coal terminals and the industry itself as a whole, it should be noted that this area does not contribute to the creation of manufacturing industries with a high share of VAT in the region. At the same time, the export direction can be considered as an uncontested option for the sustainable development of the coal industry. Therefore, first of all, the emphasis should be on the creation of the Far Eastern Metallurgical Plant and the solution of related transport 
problems. The determining factors are the availability of investments, the readiness of deposits for development, market conditions, and transport.

The competitive advantage of the Far East lies in the wealth of mineral resources, based on which it is necessary to build a strategy for economic development. The region has deposits of coal, iron, non-ferrous, rare and rare-earth metals, ore and placer gold, and building materials. These natural resources can become the basis for the creation of a developed mining complex. In this regard, state support for resource projects is necessary not only through participation in financing but also through the creation of a favorable investment climate in the region. The economic assessment of the efficiency of the development of mineral resources indicates significant potential. If investment projects are implemented, the following effects can be expected: (1) a vertically-integrated mining and metallurgical complex based on iron ore deposits [13] gross value added (GVA) will amount to $\$ 79.5$ billion and \$ 33.9 billion in tax revenues to the budgets of various level; (2) construction of a plant for the pigment titanium dioxide production [14] GVA will amount to 60.6 billion rubles, tax receipts - 18.7 billion rubles.

\section{References}

1. J. Savolainen.Resources Policy, 50, 49 (2016)

2. J. Hausner, H. Resources Policy, 52, 72 (2017)

3. Socio-economic development of the Far Eastern Federal District in the first half of 2019, (2020)

4. Regions of Russia. Socio-economic indicators. 1204 (2019)

5. A.B. Bardal. The potential for integration of the transport complex of the East of Russia into the international market of transport services, Economic and Social Changes: Facts, Trends, Forecast, 12 (2019)

6. State report "On the state and use of mineral resources of the Russian Federation in 2018" (2019)

7. G.I. Arkhipov. Mineral resources of the mining industry of the Far East. Strategic assessment of development opportunities, (2017)

8. Transport in Russia - 2018, (2019)

9. Investment portal of the Far Eastern Federal District, https://invest.minvr.ru/ru/projects/20, (2020)

10. On the approval of the passport of the investment project "Modernization of the railway infrastructure of the Baikal-Amur and Trans-Siberian railways with the development of carrying and carrying capacities", 2116-p, (2014)

11. Z. Maksimov. Modernization of approaches to seaports, (2018)

12. Federal Agency by Sea and River Transport. URL: http://www.morflot.ru (2020)

13. Yu.A. Arkhipova. Formation of vertically integrated production in the mining and metallurgical industry, (2006)

14. Yu. A. Arkhipova. Metallurg, 3, 8 (2017) 